\title{
Feasibility of Building Bridges Between School and Homes in Developing ESL Literacy: The SPIRE Project
}

\author{
Madhubala BavaHarji ${ }^{1}$, Krishnaveni Letchumanan ${ }^{1} \&$ Sareen Kaur Bhar ${ }^{1}$ \\ ${ }^{1}$ Learning Institute for Empowerment (LiFE), Multimedia University, Malaysia \\ Correspondence: Krishnaveni Letchumanan, (LiFE), Multimedia University, FCM Building $3^{\text {rd }}$ Floor, Persiaran \\ Multimedia, 63100 Cyberjaya, Selangor Darul Ehsan, Malaysia. Tel: 603-8312-5757. E-mail: \\ knaveni@mmu.edu.my
}

Received: May 6, 2014 Accepted: June 6, 2014 Online Published: August 14, 2014

doi:10.5539/elt.v7n9p91 URL: http://dx.doi.org/10.5539/elt.v7n9p91

\begin{abstract}
This paper presents a feasible framework for building bridges between schools and homes to develop five year olds ESL literacy skills, using storybooks as a springboard. A reading program, i.e. Smart Partnership in Reading in English (SPIRE) was designed in response to the government's aspiration to raise literacy rates to $100 \%$ by 2020 and the Minister of Education's call for both parents and teachers to play a more active role for reading to be developed as part of the Malaysian culture. Evidence of the positive effects of storybook reading abounds in the literature and various successful reading programs that bridges schools and home to develop L1 literacy have been carried out, particularly in the UK and USA. However, a similar approach appears to be not adopted in Malaysia. Hence, the SPIRE project was conceptualised to make schools more "permeable" and to move L2 literacy from the classroom into the L2 naturalistic context at homes. 25 multiracial children, their parents and the class teacher participated in this project. Storybooks and other multimedia materials were frequently and repeatedly read/listened to in school, and were taken home for parents to scaffold their children's ESL literacy development at home. The mixed method approach, using numerous instruments was employed to evaluate the effectiveness of the project. The study found that the children's progress corresponded to the storybook reading experiences at home. The children, whose parents displayed higher levels of involvement made faster progress compared to the children whose parents were less involved. Consequently, 16 children made substantial improvements and were independent readers at the end of the six months project.
\end{abstract}

Keywords: bridges between schools and homes, ESL literacy, reading program, storybooks, multimedia materials, reading habits

\section{Introduction}

Research evidence demonstrates that parental involvement in sharing storybooks lays the foundation for literacy in early years (Hannon \& James, 2013; Rosenthal \& Sawyers, 2012; Overett \& Donald, 2011). Builder (1993) insisted that parents be "contracted and involved ... There is no excuse for not involving parents", which Navarrette (1996) reasoned that societal pressures from the educational system are demanding so much more that the whole family involvement is a vital component of the education process. Similarly, Nathenson-Mejia, (1994) asserted that: "It is worth the time and effort on the part of the school to create strong bridges, which will allow not only the children but also the parents and teachers to communicate effectively between these two most important worlds of children." Sharing similar views, Rasinki and Frederick (1989) asserted that “... over the long run, [involving] parents is worth the effort ... parental involvement can no longer be considered an option. It is a must ...". Viewed as prime educators, parents are recognised as having "much greater value than an add-on to what teachers do" (Kruger \& Mahon, 1990 cited in Cairney \& Munsie, 2006) and hence numerous successful reading programs have been carried out to bridge homes and schools in Britain and USA. However, the concept of building similar bridges between homes and schools to develop ESL literacy has yet to be explored in Malaysia. Ample evidence suggests that involving parents can make the difference, and therefore it makes sense to capitalise on parents' expertise in developing the children's early ESL literacy. Navarrette (1996) noted that " ... until now, the [Malaysian] family has been an untapped resource that can help to prepare children academically and to give them the skills they are expected to have mastered before entering school". Their involvement is worth the while and merits attention, and thus, it is time for Malaysian schools to become more 
"permeable", for teachers to view parents as teaching partners, to move L2 literacy from the classroom into the L2 naturalistic context, and for homes and schools to work together in partnership. It is time to build bridges between homes and schools and the Smart Partnership in Reading in English (SPIRE) project conceptualised this bridge. As Nathenson-Mejia (1994) expounded, "It is important for children to feel that their home and school worlds are working together. When parents and teachers both reach out to bring the worlds closer, children are the winners".

\section{Literature Review}

\subsection{Application of Vygotsky's Key Concepts in This Study}

Vygotsky theory offers a useful framework for studying and applying social interaction between child and adult in shared literacy events (Mason \& Sinha, 1993). The social constructivist framework, which emphasises social interaction, i.e. for adults to mediate literacy development within the children's Zone of Proximal Development (ZPD) was applied to develop ESL literacy in the SPIRE project, using storybooks as a vehicle to develop ESL literacy. The scaffolding that adults offered during storybook reading sessions acted as "temporary launching platforms" (Bright at al., 2014) to more complex levels. Figure 1 illustrates the processes in adult mediated ESL literacy development.

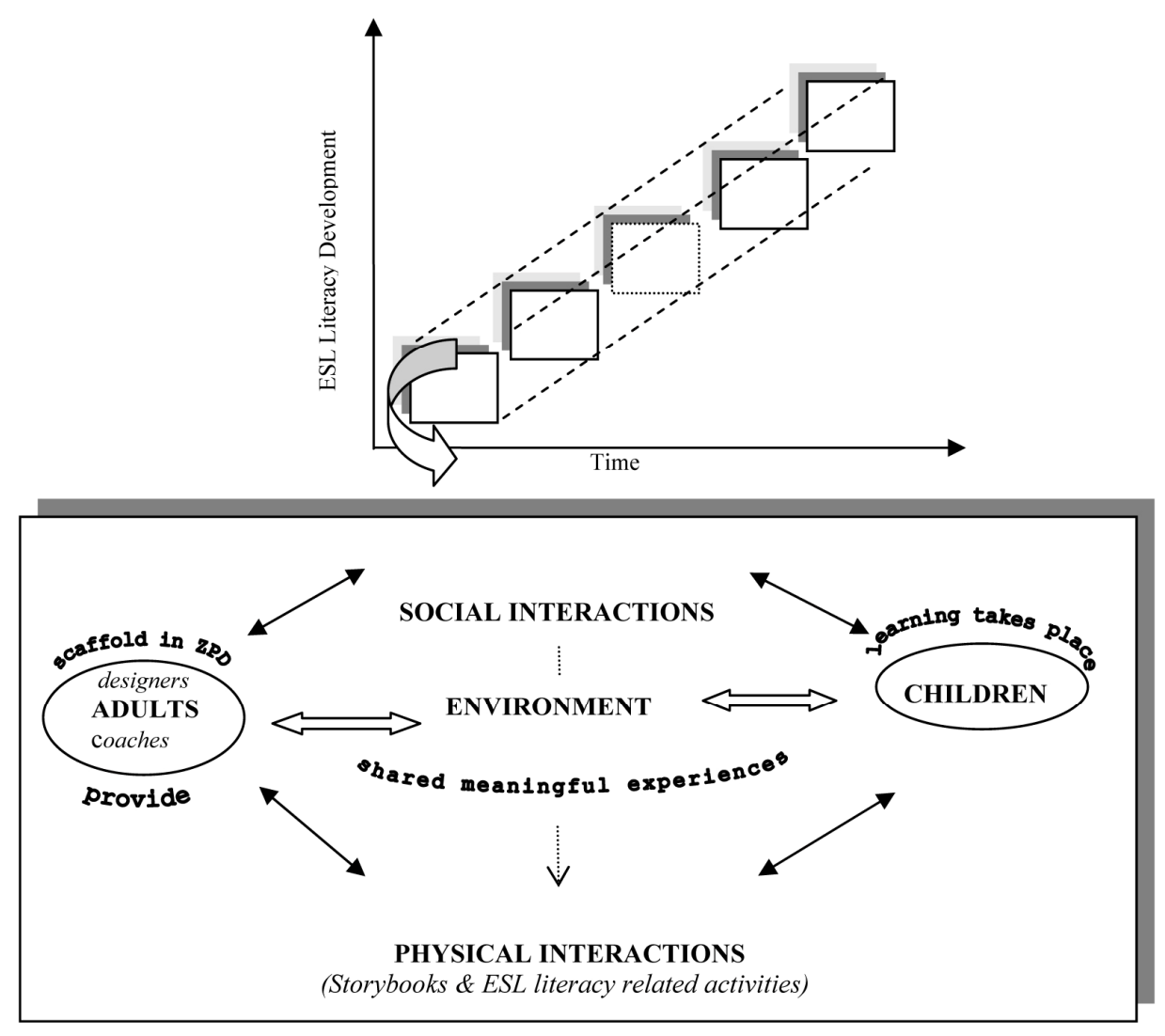

Figure 1. Adult mediation of ESL literacy in a shared meaningful environment

In Figure 1, adults, i.e. parents and teacher are seen as "designers" for physical interactions and "coaches" in the social interactions with the children. As "designers", they set the physical ESL literacy environment, create opportunities for children to engage in meaningful literacy experiences. As "coaches", their social interaction with the children helps them engage in active constructions of literacy, meaning and knowledge. They scaffold the children's ESL literacy development by providing just enough guidance for them to independently progress and learn new strategies, through the ZPD. The children develop ESL literacy skills by participating in shared meaningful experiences with adults. The application of Vygotsky's model in the project involved four processes as displayed in Figure 2. 


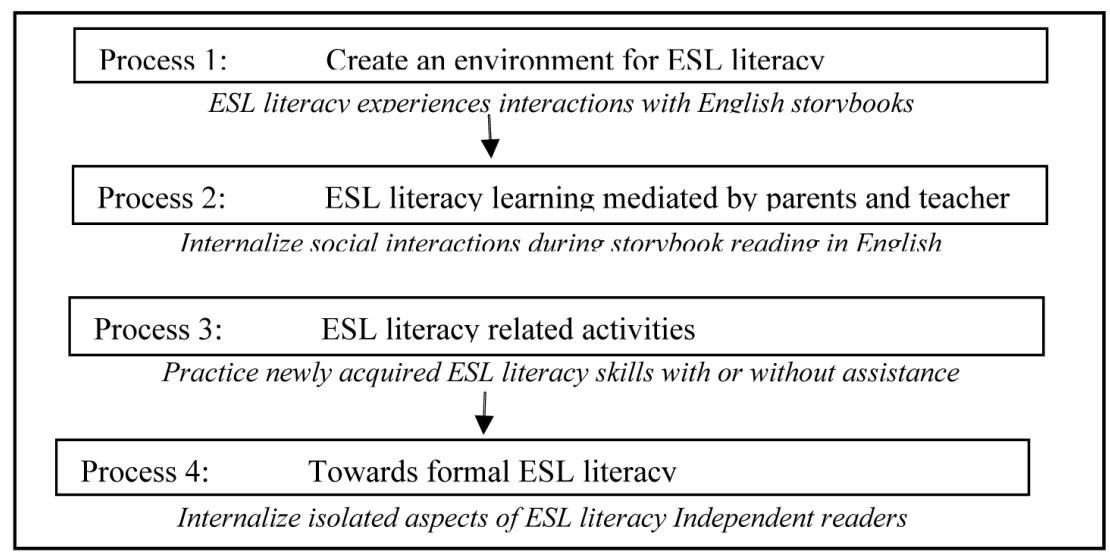

Figure 2. Application of Vygotsky's model in the SPIRE project

As seen in Figure 2, process 1 involves creating an environment for ESL literacy context for adults to take the role of "coaches" in the social interaction and "designers" of the physical environment. It aims to create links of social context, i.e. the immediate, structural and social levels (Bodrova \& Leong, 2006) and physical interaction (with storybooks and literacy-related materials). Process 2 involves creating opportunities for ESL literacy learning that is mediated by adults, i.e. for parents and teacher to mediate the children's ESL literacy learning, using storybooks and for children to internalise the interaction. Process 3 involves creating an ESL literacy environment, providing ESL literacy related activities, for the children to practice the newly acquired ESL literacy skills, i.e. with or without assistance. As the children internalise and master the ESL literacy skills, they will gradually move towards formal ESL literacy, i.e. independent readers in Process 4.

\section{Significance of the Study}

The Minister of Education (1999) asserted that both parents and teachers ought to play a more active role in developing reading habits among children: “... reading should be developed as part of our culture". The Malaysian government's aspiration to raise the literacy rates to $100 \%$ by the year 2020 (NST, 15.8.1999) is apparent in the constant reminders to parents and teachers to help arrest this shortcoming. In the light of this growing concern and challenge for parents to play a more active role in nurturing reading habits among young children, and for parents and teachers to work "hand-in-hand", the SPIRE project offers an avenue for the children's educators, i.e. both parents as prime educators (Barbour, 1999) at home and the teacher in school, to develop positive attitudes towards reading in English. The results of this study provides evidence for the feasibility of building bridges and how parents and teachers' can work together in partnership in addressing this concern.

\section{Method}

\subsection{Participants}

25 pre-school children (five- years-old and multiracial) and their parents, a project coordinator and the class teacher of Jasmine participated in this study. All 25 children were non-readers before the project. Only two children's heritage language is English. The largest group comprised children whose heritage language was Mandarin, followed by Malay, Tamil and English. Except for the two Eurasian children, the other children spoke mostly in their mother tongue in school and at home. Most of the children's English Language proficiency was limited. The teacher reported that their language proficiency was at the "one or two word(s) level", before the project. She noted that they would begin a conversation with "teacher" and complete the sentence either in Malay or Mandarin.

As for the parents, once again except for the two Eurasian parents, 13 parents spoke English and/or their heritage language at home and 10 spoke only in their heritage languages (Mandarin, Malay, Tamil). Only six parents maintained reading to their child before the project: four read once or twice a week, one read three to four times a week and one read every day. Only three parents reported they read English storybooks, the other three parents read Malay and/or Tamil storybooks. Most of them received secondary education; four parents received tertiary education. However, seven parents (four fathers and three mothers) did not receive formal education. 
The project coordinator assisted in planning, implementing and evaluating the project. She was stationed in the school $2^{1 / 2}$ months before the project commenced. She managed the project and Strawberry Club: kept records, established contact with parents, prepared newsletters (Appendix 3) and reading calendars, assisted in meetings, organised home visits, prepared training materials for parents, read to/with the children and assisted with the evaluation of the project.

The teacher positive attitude and active involvement in the project contributed to its success. She read at every possible opportunity, created storybook events in class by making time to read/tell stories, designed weekend activities to be taken home and assisted in home visits.

\subsection{Materials}

\subsubsection{Instruments}

A comprehensive evaluation, which was made against the aim of the project, was based on a variety of measures that were employed to determine the impact of the project on the children's early ESL literacy skills and the feasibility of the project in fostering a partnership between the school and homes. To gather evidence from multiple perspectives, this study employed the "many windows" approach — combinations of sources, methods and contexts (McAfee \& Leong, 2006). Firstly, a combination of various sources of information i.e. the children, parents and teacher, were used to distinct information from different perspectives. Secondly, a variety of methods and measures, i.e. as multiple indicators (Vukelich, 1997) were utilised to provide multiple forms of evidence of the children's ESL literacy development (Falk, 1998). Numerous instruments were used to gather data: Concept Print Test and Letter Identification (Clay, 1993), Teacher's Journal, Assessment portfolios, Interviews with Children and Parents, Story Grammar (Morrow, 2011), Detecting Rhymes (Gunning, 1996), Record cards (Branston \& Provis, 1999), Meetings, Weekend Activities, Informal Conference Home Visit, Miscue Analysis (Arnold, 1982), Interview with Children and Parents, Reading Log (Thompkins \& McGee, 1993), Spelling Task (Richek et al., 2013), Word Recognition (Clay, 1993), Motivation Interviews (Gambrell, 1993) and Favourite Story Book Reading (Sulzby, 1985). Data gathered from these instruments were aimed at ensuring the smooth flow of the project and monitoring its effectiveness.

\subsubsection{Materials for the Children}

To create a rich ESL literacy environment for storybook events in school and homes, a wide range of materials were made available, i.e. 363 storybooks, which were purchased, were graded using the "Criteria for Sequencing Books for Beginning Readers and Writers" (Peterson, 1991), labeled and categorised. The storybooks included: two published graded books, i.e. "The Oxford Reading Tree" (ORT) and "The Ladybird" series; books with repeated words and phrases; books with vivid pictures and large print; nursery rhymes, poems and songs; traditional literature storybooks that are well-known and favoured; shaped books, flap books, pop-up books; big books; board books, easy-to-read books with limited vocabulary and predictable texts; and wordless books. Multimedia materials, i.e. 94 VCDs and CDs were also purchased for children to read, sing or dance along.

To create opportunities for social interaction, weekend activities were sent home at the end of each week. The activities included art and craft, such as making organic book mark, mobile to little fishes, paper weight for daddy; worksheets, such as missing letters in nursery rhymes, activities linking to the ORT; serial activities, such as BBC Muzzy series, Ladybird phonic series, and "You Can Read" series.

\subsubsection{Materials for the Teacher, Project Coordinator and Parents}

Materials for the teacher and project coordinator included Teacher's role in a literacy-based reading program (Tompkins, 2013); Involving parents/reading projects (Hewison, 2011; Tizard et al., 2011; Griffiths \& Hamilton, 1984); Creating a print rich classroom environment (McGee \& Richgels, 2011; Brewer, 2006); Guidelines for reading aloud/book sharing (Gunning, 1996; Combs, 1996; Trelease, 2006); Stages in reading (Sulzby, 1985; Thompkins \& McGee, 1993) and Home school communication (Billman \& Sherman, 2002; Freeman et al., 2012).

As for the materials for the parents, a booklet on "Enriching the Book Sharing" experiences and a hand-out on "Questions Parents Commonly Ask about Young Children's Reading Behaviours" were distributed. The parents also received a reading calendar, which included suggestions for daily activities that they can do to scaffold their children's ESL literacy development. The calendar included tips on reading to child, lyrics of nursery rhymes, "tips of the month", for instance, setting up a home library, visiting the public library, talking about books and other activities, such as "create" a "Me" book. Either letters or newsletters (Appendix 4) were also distributed weekly to provide continuous support to parents and to highlight the notion of partnership between the teacher and parents. 
The PACT (Appendix 2), which is an agreement among the children, parents and teacher to work together in partnership towards developing the children's ESL literacy skills was signed by all parties. The children promised to read with/read to their parents, fill in the record cards and take care of the reading materials they take home. Parents pledged to spend time regularly on reading/listening to their children, to monitor their child's ESL literacy growth, to receive and respond to oral/written communication from the teacher. The teacher promised to make parents feel welcomed, communicate and work with parents and to encourage the love for reading among children.

\subsection{Time Frame}

The project ran over a duration of six months.

\subsection{Data Collection Procedures}

The framework (Appendix 1) of the SPIRE project was conceptualised in six stages (Starting Point: First Considerations; Planning the Project; Getting Started; Implementation; Maintaining and Monitoring; Measurement and Evaluation) and each stage was not discrete and exclusive, overlaps are inevitable and cross-references were made to avoid repetition. Due to the limitation of the length of this paper, brief descriptions of the stages are made in this section.

At the starting point, pertinent considerations as listed in the framework were made. The Smart Partnership in Reading in English or the acronym SPIRE project was coined to reflect one of the aims of the project, i.e. to establish a partnership between parents and teacher, via reading storybooks in English.

The planning stage included setting up a reading corner, replacing the cupboard box with some old and tattered storybooks in the classroom. The storybooks were replaced weekly to attract the children to the corner. It created a sense of excitement as the children looked forward to new storybooks:

...There is a reading corner with lots of colourful and interesting storybooks now, ... before the project, we only had plain, old and tattered books. The children now just love to go to the reading corner because there are lots of new books every week ...they always look forward to the new storybooks ... (Celine/I2)

A "Strawberry Club" was also set up to create an inviting atmosphere for ESL literacy 'centre', i.e. for the children to have access to the rich choice of storybooks. The children always looked forward to Thursdays to be in the club:

... the children were always eager to go to the Strawberry Club ... they are always excited when it comes Thursday ... always pestering me to bring them to the club. They are always bugging me why it's not Thursday... at the club, they rush for their favourite storybooks ... trying to get their hands on the best storybooks to bring home ... children feel as though they are in a fairyland that is filled with books that are colourful, books with music and shaped books. They spent their time reading the storybooks, lazing around on the carpet, on the floor ... comfortable sofa and long bench ... almost everywhere in the club ... when the time is up they will feel disappointed because they want to spend more time surrounded with storybooks ... (TJ)

In getting started, a month before the project was implemented, an introductory letter, describing the project was distributed through the children. Parents were given the option to refuse participation and only one parent opted out. During the launching of the project, parents briefed on.

In implementing the project and creating storybook events in the class, the teacher read storybooks aloud, which was not a practice before the project. She adopted the lap method (McCracken \& McCracken, 1987), i.e. a child seated on a parent's lap, with a storybook held in front of him and a parent, and interactive storybook reading technique. She read regularly and repeatedly at every opportunity.

Parents were encouraged to read aloud/listen to/read with their children, listen to taped stories/rhymes together and discuss stories together to scaffold the children's early ESL literacy development within the ZPD and to create storybook events at home. They were encouraged to spend approximately 10 minutes a day with their children.

In maintaining the project, keeping lines of communication open was crucial to sustain links between parents and teacher. Regular contacts were established through various "communication lines": (i) Record cards (Appendix 3) were sent out together with the reading materials taken home. Parents expressed their views of the materials their children took home, noted their children's reactions/responses to the materials, noted their children's ESL literacy development at home and communicated with the teacher. To give the children a sense of ownership, they were encouraged to express their views (in the form of drawings or writing) in the cards. (ii) 
A total of four follow-up meetings held throughout the project. During these meetings, a demonstration on how to read interactively was made, storybook reading experiences were shared and concerns were raised. A Book Making Session was held and all the parents who attended this session made favourable comments about making storybooks. (iii) The assessment portfolio reports, which included the children's interest in books and reading, reading skills and behaviours, and reading progress were given to parents, who were able to get a clear picture of their child's progress within the school walls (iv) home visits, which were aimed to foster partnership between parents and teacher as well as share information on "good practice" for developing literacy skills and encourage parents to read interactively to children (v) phone calls (vi) letters and newsletters and (vii) informal conference.

In maintaining and monitoring the project, routine checks on practicalities of records of storybooks, maintaining parental participation and monitoring progress, which are essential elements to monitor the pace and momentum of the project were carried out.

\section{Findings and Discussion}

The results of the evaluation of the project clearly points to the feasibility to building bridges, via parental involvement in developing ESL literacy; in partnership between homes and school. In presenting the findings, the participants' comments are inserted to give a more lucid picture of the project. Pseudonyms are used to conceal their identity: (P/Nurul) refers to Nurul's parent, (RC/Syafa) refers to Syafa's record card, (WA/Rishi) refers Rishi's weekend activity, (TJ) refers to the teacher's journal, (HV/Veron) refers to a visit to Veron's home and (Celine/I) refers to Celine's (teacher) responses during the interview. All quotes are verbatim and translated versions are presented when parents spoke in the Malay language. Key words or phrases on various aspects of ESL literacy are italicised.

One of obvious findings of this study is that it is feasible to build bridges between homes and school. The teacher's initial perception that a partnership may be impossible “... a bit difficult because parents feel that it's the teacher's job to teach the children ... parents would not want to be involved ... have no time or busy with work ..." changed in the course of the project. She reported that "... it works! ...":

... This project has also made parents and teacher as partners in their child's affairs, not only in their education, but also in knowing them better as a child him/herself. This can be seen during the home visit that we made. We can understand the children's reading development together and the parents can get to know their child's progress in class ... its easier to discuss when parents and teachers are close. Both the children and parents tend to respect me more because I show that I am concerned with the child's progress. The partnership is not impossible. It works! ... (TJ)

The concept of partnership had extended to a partnership among all members of the family in some homes. The weekend activities provided the opportunity to foster this partnership:

... My daughters both enjoyed colouring, cutting of the fishes ... [Grace] kept singing the song "10 little fishes" to her sister. It's good thing to do over the weekend. Thank you for the great job you're doing. (WA/Grace)

... We didn't do the kitchen assignment but I did ask her to show me items like milk, milo, Nestum, etc. Since we didn't have a carrot available, we used anions instead. These onions had names (given by Charlene) but so far, no sign of growth. So, Charlene's dad bought some green beans yesterday and hopefully it will grow ... (WA/Charlene)

The findings of this study also points to the clear links between parental involvement and reading progress. Although all the children displayed progress in their reading ability, there was a substantial difference in reading progress, which corresponded to the levels of involvement and the storybook reading experiences at home.

Two broad levels, i.e. high and low levels of parental involvement were evident. The 16 children whose parents displayed high level of involvement, read more frequently and repeatedly to scaffold their children's reading development within the ZPD noted that they spent more time reading than the suggested time, which was only 5 to 10 minutes a day to their child:

... Now he brings more storybooks, so I spent more time with him. This project, parents have to play a part, actually I spend more than one hour reading ... his father will read in the evening ... I also read to him everyday and before he goes to bed, there is sure one [read to him] ... even 12.00 p.m. also we are used to already because we are following your project ... (P/Akhil)

... My child loves to read, that is why I read to him more than one hour ... (P/Selva) 
... I am very busy, but I will make it a point to read to her because she is very interested in storybooks that she brings home ... I try to spend about 20 or 30 minutes ... (P/Nurul)

These children made remarkable progress and were reading independently or with minimal assistance from adults. They progressed from being dependent readers or even refusing to read, to independent readers. There was a "hand over principle" (Bruner, 1983), i.e. the children's changing role in being read to by an adult to read independently of with an adult.Conversely, the nine children whose parents were less involved, made slower progress as they received less scaffolding and had fewer opportunities for storybook events at home. Their parents read for 10 minutes or lesser:

... I [mother] very busy ... afternoon I put the children at the grandmother house than I go work ... only night I read to [Veron] not long lah maybe 10 minutes or less like that ... (P/Veron)

... I read to him occasionally ... we should read to him since we are at home ... I read to him, but I do not have a fixed time ... I read when I am free ... (P/Qarim)

Another obvious finding was that all parties, i.e. the children, parents and the teacher displayed attitudes toward storybook reading. The children displayed positive attitudes and behaviour toward reading storybooks in school :

... In my reading corner there are now pull out drawers full of storybooks, ... they will go voluntarily now ... very eager to be at the corner ... they will take out the mat and put it on the floor and choose two to three books to read comfortably on the mat or some of them will take a book and go to a quiet corner to read by themselves ... now they have begun to love reading because when there's time, they will be rushing to get the best book for themselves... Their whole attention will be on the books and their faces will be glowing with interest in reading and knowing a story ... they are indeed very excited with all the storybooks and they are immersed in a "world" of reading materials that are in the Strawberry Club ...

As well as at home:

... She was always asking me to read, read ... she always pesters me to read to her ... (P/Charlene)

... He will be bugging me ... mummy read ... he will follow me and even waits outside the toilet ...pleading ... please read mummy... (P/Ravi)

... Her father says that she enjoys listening to her mother read to her so much so that she asks her mother to read stories every night before bed time ... (HV/Charlene)

Most parents also displayed positive attitudes and behaviors towards reading storybooks too:

... Last time I don't think story reading is important but now is quite important ... Yes, I do buy storybooks now, before I buy activity books only ... (P/Chee Sze)

... Now birthday or any occasion, I tell them it's better if you give storybooks ... (P/Charlene)

... Most of the parents have developed positive attitudes towards storybook reading and viewed it as a valued activity ... (TJ)

Positive attitudes towards storybook reading was also displayed by the teacher. In contrast to sporadic storybook reading before the project,

... I can say that I only have my storytelling session once a month and may be even lesser ... only if there was a few minutes to spare ... I don't placed importance on it and so it does not matter if I don't read to them ... (Celine/I2)

the teacher read more often and at every possible opportunity to do so.

... I started reading more often when the project was implemented ... I started to do story telling in the morning during the first period ... I read everyday for 20 to 25 minutes... I make sure that there will be a time for story reading everyday or if any opportunity arises, I will grab it, for example, in mornings when the children assemble in the hall before lessons start... I will put the storybooks in a bag ... the very minute the children sees the bag they will rush to me to get a book for me to read to them ... (Celine/I2)

Interestingly, storybook reading experience was not confirmed to only the parents and children, it had extended to include other family members. It appeared to be a joint social event:

... If I'm working or busy my elder daughter will read to [Charlene] ... her sister too enjoys the stories that she brings home ... (P/Charlene)

... It's not only that [Ravi] will be reading ... sometimes his elder brother and younger sister will be joining in to read together or just to listen to him ... and sometimes his elder brother will read to him or it will be 
the other way around ... sometimes he will read to his younger sister ... (P/Ravi)

... As her father is always outstation, her aunty will read to her and discuss the stories ... (HV/Christie)

... Her cousin will read to her, as her mother doesn't read much English ... (HV/Chiew Wen)

... [Priya's] grandmother reads to her by using the picture cues to tell the story ... (HV/Priya)

... Her maid will read to her and she doesn't mind it as long as someone is reading to her ... (HV/Hiew Jian)

The wide range of storybooks and multimedia materials created a rich ESL literacy environment. A parent noted “... with the SPIRE project, he gets a variety of books and it makes it really interesting for me as well ... The books that I have for him don't have much repetition. The books that are in the Strawberry Club - it's an eye opener. I find the levels helpful ... (P/Gary)". The materials were favoured for various reasons.

"The Oxford Reading Tree" (ORT) and "The Ladybird" series, the two published graded books helped develop the children's confidence:

... he likes the O.R.T because he can read the words and the story is interesting ... (P/Yasim)

... she wants to read every time, especially the O.R.T books because they are easy to read and gives her the confidence to read the book ... when she knows how to read than she's eager to read ... (P/Nurul)

Storybooks with repeated words and phrases provided the opportunity to revisit words and memorise phrases, repetitive refrains, which the children were able to recognise:

... These storybooks have repeated words or phrases ...they are able to recognise the words and will point it out, saying "teacher, teacher they are the same words" For example, "Hello, Can you see me" ... and repeated phrases like the book "I'm just joking, said the lobster", they will read it aloud together like in chorus ... (TJ)

Nursery Rhymes, Poems and Songs helped develop the children's phonological awareness, cultivate their endowment to recognise sounds that are similar and develop an awareness of the rich and varied language.

The easy-to-read books, with limited vocabulary and predictable texts were especially useful in the initial phases of the children's reading development. These books aided in learning to read independently, gave the children a sense of ownership and a sense of achievement and motivation to read on.

... he likes the book "Where is the fish?" because it is easy and he is able to read this book. He is more motivated and confident to read ... (P/Selva)

Shape storybooks/Flap books/Pop up books were appealling:

... [Farah] loves storybooks that have shapes and music. She will be the first one to grab these types of books ... [Qarim] will run to the book shelf first to get his hands on the pop-up books, like "Jack and the Beanstalk" ... [Yasim, Qarim, Rishi] were very interested in the "lift-the-flap"- The noisy Farm - they were almost "fighting" for it, but later took turns to look at it ... they kept guessing what is behind the flap until they get it right (TJ)

Big books, with enlarged texts enabled the children to see and react to the printed pages as it is read aloud.

... It is easier with the big books to read stories to the children because all the children can see the print and the pictures and they even pointed out words that are repeated. They like the books because they can read along with me ... (TJ)

Board storybooks were easier to handle:

... [Veron] will rush for the board storybooks because she finds it easy to turn the pages

Wordless books helped develop the children's imagination

... initially he was "reading" the storybook that he brought home ... but when I looked at the book, there ere no sentences ... he used his imagination to create a story, ... it's a good book ... (P/Yasim)

The multimedia materials were also favoured as the children were able to read, sing or dance along. These materials created a social event with family members too:

... with this video all of us enjoyed ourselves and it was a nice pass time. ... (RC/Selva)

...when he brings home the tapes, he is sure to watch ... didn't take off his school uniform ...asks me to switch on the TV for him to watch ... he said now I must watch and he will sing and dance too ... (P/Akhil) 


\section{Conclusion}

Clearly, this study shows that the school walls have become more 'permeable' and a bridge has been built between homes, i.e. the child's first classroom (Barbour, 1999) and school. The teacher consented that it is worth while to involve parents, the prime educators and to work together in partnership for the benefit of the children. Hence, it will be a grief disservice to young children, if pre-schools do not engage parents in developing ESL literacy. It is time to recognise the importance of the strong links between children's home and school and to .mobilise this powerful influence to spur the children's reading skills. It is time, as Newson and Newson (1977) asserted, i.e. for a "revolution in [ESL] literacy ... [to be] ... sparked off and fueled by parents and teachers in determined co-operation". The children's storybook events and reading experiences in school and homes have clearly been the most crucial event in ushering them into the world of ESL literacy and reading. As one parent noted:

... "In my opinion the SPIRE was indeed a true success, it has made a dramatic impact on my two boys" life and have helped to create two boys who will be readers for life. The project is a success ... (P/Gary)

\section{References}

Arnold, H. (1982). Listening to Children Reading. Sevenoaks, Kent: Hodder \& Stoughton.

Barbour, A. C. (1999). Home Literacy Bags : Promote Family Involvement. Childhood Education, 75(2), 71-75. http://dx.doi.org/10.1080/00094056.1999.10521986

Billman, J., \& Sherman, J. A. (2002). Observation and Participation in Early Childhood Settings (2nd ed.). Boston: Allyn \& Bacon.

Bodrova, E., \& Leong, D. J. (2006). Tools of the Mind: The Vygotskian Approach in Early Childhood Education (2nd ed.). Englewood Cliffs, New Jersey: Merrill.

Branston, P., \& Provis, M. (1999). Children and Parents Enjoying Reading (Tch ed.). London: Hodder and Stoughton.

Brewer, J. A. (2006). Introduction to early childhood education: preschool through primary grades (6th ed.). Boston: Allyn and Bacon.

Bruner, J. (1983). Child's Talk: Learning To Use Language. Oxford: Oxford University Press.

Builder, P., \& Australian Council for Educational Research. (1993). Exploring Reading: Empowering Readers with Special Needs. Hawthorn, Vic; Australia: Australian Council for Educational Research Ltd.

Cairney, T., \& Munsie, L. (2006). Talking to Literacy Learners: A Parent Education Project. Reading, 26(2), 34-48. http://dx.doi.org/10.1111/j.1467-9345.1992.tb00062.x

Clay, M. M. (1993). The Early Detection of Reading Difficulties: A Diagnostic Survey with Recovery Procedures. Auckland, NZ: Heinemann Educational Books.

Combs, M. (1996). Developing Competent Readers and Writers in the Primary Grades. Reno: University of Nevada.

Freeman, N. K., Decker, C. A., \& Decker, J. R. (2012). Planning and Administering Early Childhood Programs. New York: Merrill Pub. Co.

Falk, B. (1998). Testing the Way Children Learn: Principles for Valid Assessments. Language Arts, 76(1), 57-66.

Gambrell, L. B. (1993). Me and My Reading Scale In The impact of Running Start on the reading motivation of and behaviour of 1st grade children (Research Report). College Park: University of Maryland National Research Centre.

Griffiths, A., \& Hamilton, D. (1984). Parent, Teacher, Child: Working Together in Children's Learning. London: Methuen \& Co.

Gunning, T. G. (1996). Creating Reading Instruction for All Children. Boston: Allyn \& Bacon.

Hannon, P., \& James, S. (2013). Parents' and Teachers' Perspectives on Pre-school Literacy Development. British Educational Research Journal, 16, 259-272. http://dx.doi.org/10.1080/0141192900160304

Hewison, J. (2011). The Long-Term Effectiveness of Parental Involvement in Reading: A Follow-up to the Haringey Reading Project. British Journal of Education Psychology, 58, 184-190. http://dx.doi.org/10.1111/j.2044-8279.1988.tb00891.x 
Bright, R. M., Pollard, M. J., Tompkins, G. E., \& Winsor, P. J. T. (2014). Language Arts: Content and teaching strategies (6th ed.). Canada: Pearson Education.

Jalongo, M. R. (2006). Early childhood language arts (4th ed.). Boston, MA: Allyn \& Bacon.

Mason, J. M., \& Sinha, S. (1993). Emerging Literacy in the Early Childhood Years: Applying a Vygotskian Model of Learning and Development. In B. Spodek (Ed.), Handbook of Research on the Education of Young Children (pp. 137-150). New York: Macmillan Publishing Co.

McAfee, O., \& Leong, D. (2006). Assessing and Guiding Young Children's Development and Learning (4th ed.). Boston: Allyn \& Bacon.

McCraken, M., \& McCraken, J. (1987). Reading is only the tiger's tail (12th ed.). San Rafael, California: Ledwig Press.

McGee, L. M., \& Richgels, D. J. (2011). Literacy's Beginnings: Supporting Young Readers and Writers (6th ed.). Boston: Allyn \& Bacon.

Morrow, L. M. (2011). Literacy Development in the Early Years: Helping Children Read and Write (7th ed.). Boston: Allyn \& Bacon.

Nathenson-Mejia, S. (1994). Bridges Between Home and School: Literacy Building Activities for Non-Native English Speaking Homes. The Journal of Educational Issues of Language Minority Students, 14, 149-164.

Navarette, Y. G. (1996). Family Involvement in a Bilingual School. Retrieved from http://www.ncbe.gwu.edu/miscpubs/jeilms/vol16/jeilms1606.html

Newson, J., \& Newson, E. (1977). Perspective on School at Seven-Years Old. London: George Allen and Unwin.

Overett, J., \& Donald, D. (2011). Paired reading: Effects of a parental involvement programme in a disadvantaged community in South Africa. British Journal of Education Psychology, 68, 347-356. http://dx.doi.org/10.1111/j.2044-8279.1998.tb01296.x

Peterson, B. (1991). Selecting Books for Beginning Readers. In D. E. Deford, C. A. Lyons, \& G. S. Pinnell (Eds.), Bridges to Literacy (pp. 119-147). Portsmouth, N H: Heineman.

Rasinski, T. V., \& Federicks, A. D. (1989). Can Parents Make a Difference. The Reading Teacher, 43(1), 84-85.

Richek, A. M., Caldwell, J. S., Jennings, J. H., \& Lerner, J. W. (2013). Reading Problems: Assessment and Teaching Strategies (7th ed.). Boston: Allyn and Bacon.

Rosenthal, D. M., \& Sawyers, J. Y. (2012). Building Successful Home/School Partnerships: Strategies for Parent

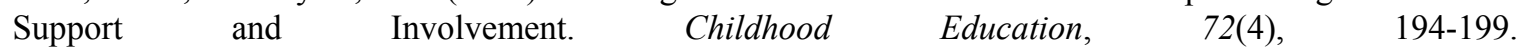
http://dx.doi.org/10.1080/00094056.1996.10522652

Sulzby, E. (1985). Children's Emergent Reading of Favourite Storybooks: A Developmental Study. Reading Research Half Yearly, 20(4), 458-481. http://dx.doi.org/10.1598/RRQ.20.4.4

Sulzby, E. (1985). Kindergarteners as Writers and Readers. In M. Farr (Ed.), Advances in writing research (Vol. 1: Children's early writing development). New Jersey: Ablex Publishing Corporation.

Tizard, J., Schofield, W. N., \& Hewison, J. (2011). Collaboration Between Teachers and Parents in Assisting Children's Reading. The British Journal of Educational Psychology, 52, 1-15. http://dx.doi.org/ 10.1111/j.2044-8279.1982.tb02498.x

Tompkins, G. E. (2013). Literacy for the Twenty-First Century: A Balanced Approach (6th ed.). Pearson.

Tompkins, G. E., \& McGee, L. A. (1993). Teaching Reading With Literature: Case Studies to Action Plans. Toronto: Maxwell International.

Trelease, J. (2006). The Read-Aloud Handbook (6th ed.). New York: Penguin Books.

Vukelich, C. (1997). Assessing young children's literacy: Documenting growth and informing practice. The Reading Teacher, 50(5), 430-434. 


\section{Appendices}

Appendix 1. Conceptual Framework of the SPIRE project

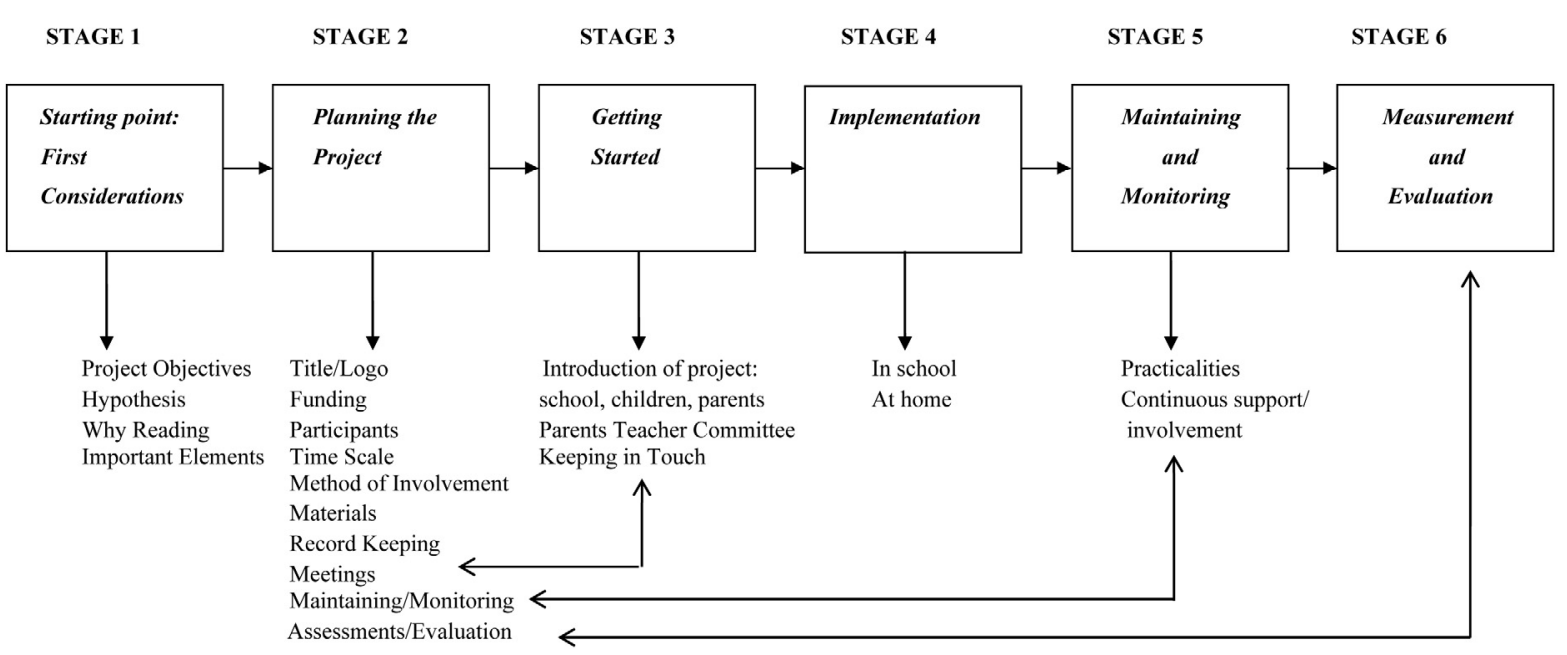

Appendix 2. The PACT (in the form of a booklet)

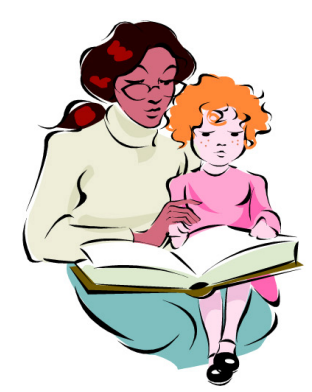

"When parents help their child learn to read, they open the door to a big, exciting world. As a parent, you can begin an endless chain where your children can develop a love of reading and thus their world will be forever richer and wider."
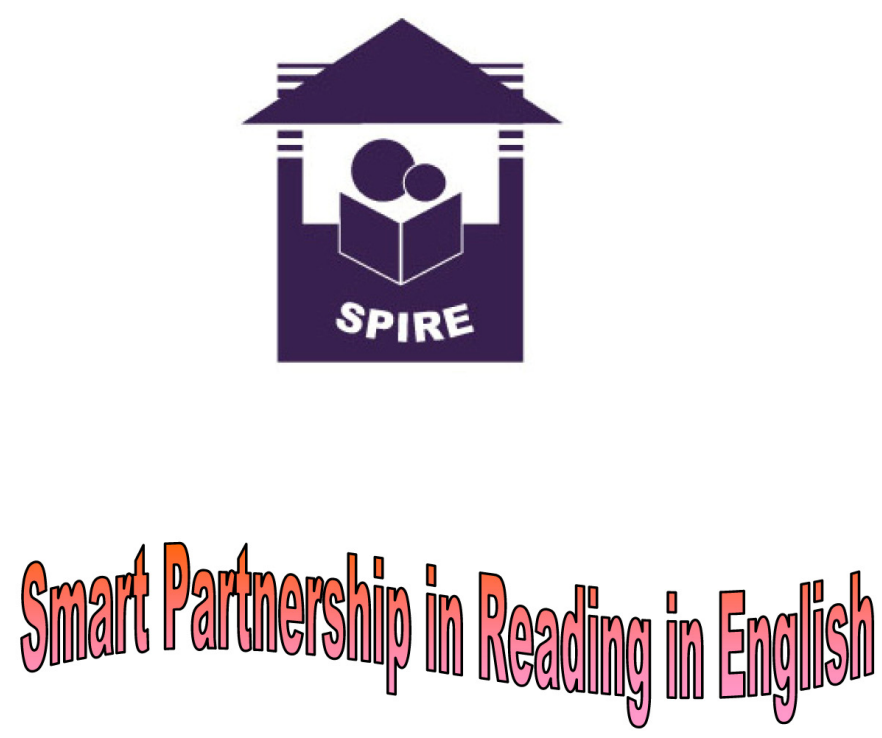
As the teacher, I promise ...

$\checkmark$ to provide a safe and healthy learning environment for the children

$\checkmark$ to communicate and work with families to support their child's reading

$\checkmark$ to make parents feel welcome

$\checkmark$ to encourage the learning of English and reading in an interesting and engaging way

$\checkmark$ to involve parents in the learning to read process

$\checkmark$ to provide an opportunity for families to engage in and train in effective reading techniques

$\checkmark$ to show respect and care for each child

$\checkmark$ to respect the cultural differences of the children and their families

Teacher's Signature

As a parent, I promise...

$\checkmark$ to help my child attend school regularly

$\checkmark$ to schedule reading time and to read for at least 15 minutes to my child everyday

$\checkmark$ to offer praise and encouragement while listening to my child read

$\checkmark$ to help monitor and assess my child's reading progress

$\checkmark$ to discuss my child's reading progress with his/her teacher regularly

$\checkmark$ to receive and respond to written/oral communications from the teacher/project co-ordinator

$\checkmark$ to ensure that the materials my child brings back from school are duly returned in good condition

$\checkmark$ to give my time and support towards the SPIRE Project

Parent's Signature

Dear Mummy/Daddy and Teacher,

As a student, I promise

- to read to/read with my parents for at least 15 minutes a day

- to fill in the record card after each session of reading

- to take good care of the materials that I take home

Let's sign this pact together to make the SPIRE Project a success and lead me on the path of developing my reading skills.

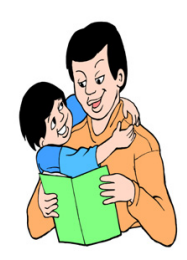

Child's Signature

Appendix 3. Record Card (Sample for Parents)

$$
\text { Record Card }
$$

Child's Name:

\begin{tabular}{|l|l|l|}
\hline Title of Book & This book was ................. for my child & Parents' Comments \\
\hline 1) & 1) *very difficult/difficult/easy/very easy & 1) My child enjoyed reading this book. \\
$2)$ & 2) *very difficult/difficult/easy/very easy & 2) My child tried reading this book but \\
$3)$ & 3) *very difficult/difficult/easy/very easy & did not manage to. \\
\hline
\end{tabular}




\begin{tabular}{|l|l|l|}
\hline 4$)$ & 4) *very difficult/difficult/easy/very easy & $\begin{array}{l}\text { 3) My child enjoyed this book very much } \\
\text { and read the book to his family many } \\
\text { times! }\end{array}$ \\
\hline Others & Parents' Comments \\
\hline Tape T2 & This is the second time my child has borrowed this video and he still enjoys it very much \\
\hline Viedo & \\
\hline VCD & \\
\hline CDR &
\end{tabular}

* please delete where appropriate

\begin{tabular}{|l|l|}
\hline Yes/No & Read/Listen Together (With Whom? \\
\hline Yes/No & Read/Listen Alone \\
\hline Yes/No & Read Aloud (To Whom? \\
\hline Yes/No & Discuss The Story Together \\
\hline
\end{tabular}

Time spent reading together this week: minutes

Signature: $\quad$ Date:

My name is:

Title of book:

(:) I liked this book. : :I did not like this book.

This book was very difficult/difficult/easy/very easy for me.

Title of book:

(:) I liked this book. : :I did not like this book.

This book was very difficult/difficult/easy/very easy for me (Branston \& Provis, 1999).

Appendix 4.

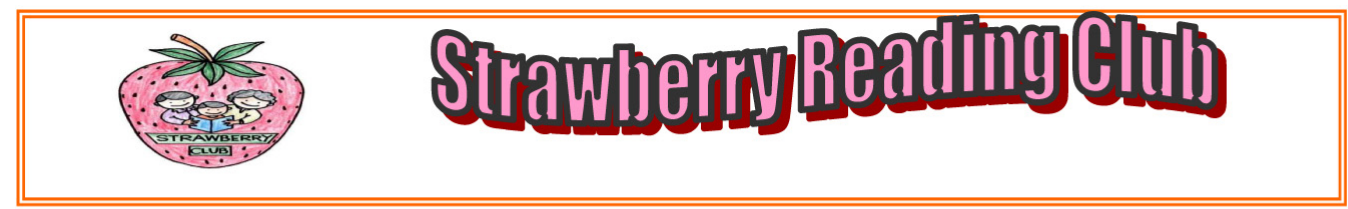

This week there is a new look to the record cards. Please cross out the level that you think is applicable to your child. You may comment on each book in the right-hand column. Get your child to do the same on the back page. Encourage them to write their thoughts on the book, maybe draw a scene from the book.

Below the table for the books is an additional table for the other materials that your child might have borrowed e.g. cassette or video. Please let us know if your child enjoyed them or if the copy was clear or not.

We will not be limiting the children from borrowing the books, which they might find difficult, as we want the children to continue to have access to a variety of books.

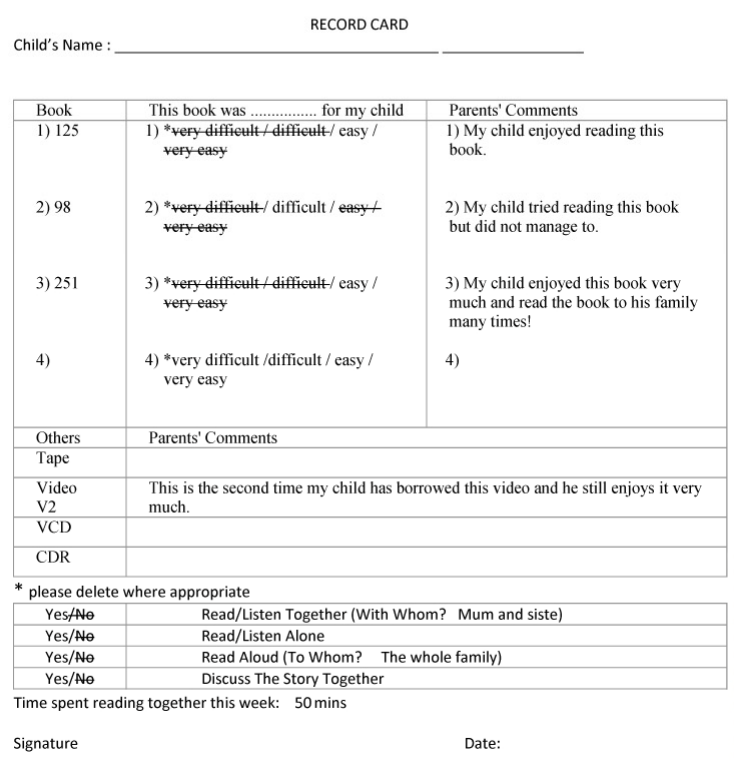



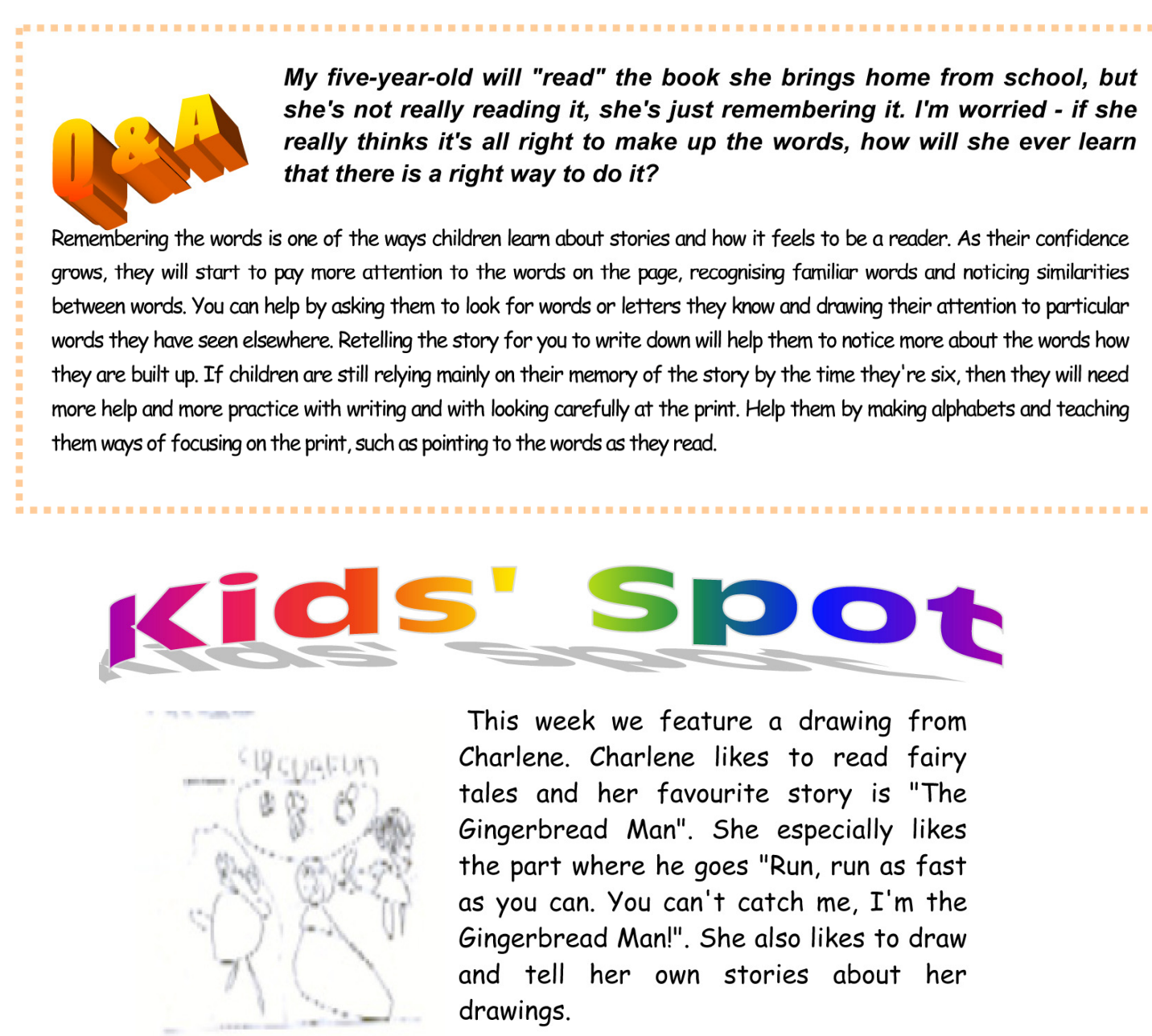

This week we feature a drawing from Charlene. Charlene likes to read fairy tales and her favourite story is "The Gingerbread Man". She especially likes the part where he goes "Run, run as fast as you can. You can't catch me, I'm the Gingerbread Man!". She also likes to draw and tell her own stories about her drawings.

This weekend's activity is making simple finger puppets that you can do together with your child. The instructions and pattern template is attached to this newsletter. Help your child to draw and glue the pieces together but encourage them to do the activity themselves. Remember it is not the result but the effort that is important.

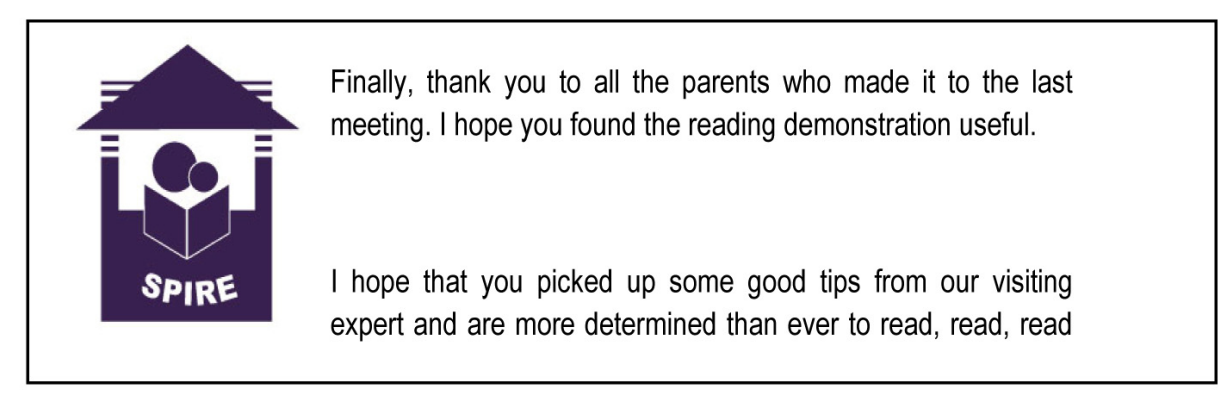

\section{Copyrights}

Copyright for this article is retained by the author(s), with first publication rights granted to the journal.

This is an open-access article distributed under the terms and conditions of the Creative Commons Attribution license (http://creativecommons.org/licenses/by/3.0/). 